\title{
Literatuur leren onderzoeken in de klas
}

Hoe de Geschiedenis van de Nederlandse literatuur en LitLab.nl scholieren kunnen opleiden tot literatuuronderzoekers

Lucas van der Deijl, Feike Dietz en Els Stronks

NEDLET 23 (3): 235-255

DOI: 10.5117/NEDLET2018.3.002.VAN

\begin{abstract}
Literary research in the classroom. Research education using LitLab.nI and the Geschiedenis van de Nederlandse literatuur

In Dutch secondary schools, pupils rarely learn how to research Dutch language and literature. While other school subjects promote the development of disciplinary research skills, the curriculum of Dutch lacks a similar focus. As a result, secondary school pupils are taught to treat the Dutch literary history as a collection of literary and historical facts rather than a status questionis of the current field of literary scholarship. In this article we argue that the connection between the Geschiedenis van de Nederlandse literatuur (GNL) and LitLab.nl - a digital laboratory for literary research on secondary schools - could support the development of a scientific research disposition and facilitate the shaping of pupils as literary researchers. We discuss the theoretical and didactic background of LitLab in order to demonstrate how an adjusted and more accessible version of the new GNL could be integrated in the curriculum by using LitLab as a medium.
\end{abstract}

Keywords: literature education, research skills, secondary schools, Dutch literature, literary history 


\section{Op weg naar wetenschappelijke nieuwsgierigheid: de symbiose tussen LitLab en de $G N L$}

De acht kloeke delen van de Geschiedenisvan de Nederlandse literatuur (GNL) zijn betrekkelijk ontoegankelijk voor leerlingen en docenten op middelbare scholen. Dat komt zeker niet alleen omdat ze dik en kostbaar zijn, of omdat wetenschappelijke inzichten zozeer met het historiografische narratief verweven zijn dat ze maar in beperkte mate als naslagwerk kunnen dienen: de belemmerende factor is met name dat de $G N L$ een onderzoekende, multiperspectivistische houding veronderstelt die in het huidige schoolvak Nederlands in Nederland niet of nauwelijks wordt ontwikkeld en aangemoedigd.

Het leren doen van letterkundig onderzoek ontbreekt volledig als eindterm in het curriculum Nederlands in Nederland. De eindtermen voor het domein 'Literatuur' voor de Nederlandse bovenbouw - het vierde en vijfde jaar van het Hoger Algemeen Voorbereidend Onderwijs (havo) en het vierde, vijfde en zesde jaar van het Voorbereidend Wetenschappelijk Onderwijs (VWO) - zijn opgedeeld in: 1) literaire ontwikkeling (= beargumenteerd verslag uitbrengen van leeservaringen); 2) literaire begrippen (= literaire tekstsoorten herkennen en literaire begrippen hanteren in de interpretatie van literaire teksten) en 3 ) literatuurgeschiedenis (= een overzicht geven van de hoofdlijnen van de literatuurgeschiedenis, en de gelezen literaire werken plaatsen in dit historisch perspectief). ${ }^{1}$

Niet alleen in de eindtermen maar ook in de praktijk lijkt slechts een marginale plaats weggelegd voor het leren onderzoeken binnen het hele schoolvak Nederlands. Lesmethoden voor het literatuuronderwijs bevatten weliswaar af en toe een opdracht met een onderzoekend karakter - bijvoorbeeld opdrachten uit de methode Laagland van het type: 'maak gebruik van bronnen', 'onderzoek wat je kunt schrijven maar niet kunt verfilmen', 'vergelijk enkele literaire werken' ${ }^{2}$ - maar van training in onderzoeksvaardigheden, laat staan het aanleren van een onderzoeksattitude, is geen sprake. Docenten ontwikkelen soms zelf lesmateriaal met een onderzoeksdoel: zo beschrijven Sigmans en Kieft in Levende Talen Magazine (2007) hoe zij leerlingen onderzoek hebben laten doen naar het leesgedrag van medeleerlingen.

Het uitgangspunt van deze bijdrage is dat het gebrek aan onderzoekstraining in het schoolvak een probleem is. Leerlingen uit wat toch het hoger of zelfs voorbereidend wetenschappelijk onderwijs zou moet zijn, brengen geen basale onderzoekende houding ten opzichte van de Nederlandse taal en cultuur mee naar hun latere beroepspraktijk. Ze leren niet dat taal en literatuur ambigu, veelzijdig en complex zijn, en dat die complexiteit vragen oproept waarop we via systematisch onderzoek gefundeerde antwoorden kunnen 
formuleren. Ze ontwikkelen niet het bewustzijn dat taal en literatuur altijd uitnodigen tot verschillende perspectieven en vanuit die perspectieven onderzoekbaar zijn, terwijl die multiperspectiviteit wel voortdurend een rol speelt in maatschappelijke discussies die in Nederland in de breedte van de hele samenleving worden gevoerd. We denken bijvoorbeeld aan de rol van taal en literatuur binnen discussies over de meertalige of de Nederlandse identiteit, over beeldvorming en representatie in literatuur en andere media, en over de culturele herinnering van de nationale geschiedenis. Het schoolvak Nederlands is bij uitstek geschikt voor het aanleren van zo'n multiperspectivistische houding, zodat (ook) leerlingen die later gaan werken als arts, docent, manager, politicus of bestuurder, zich bewust zijn van het belang van een multiperspectivistische houding in dergelijke maatschappelijke debatten.

Deze algemene gevolgen van het gebrek aan onderzoekstraining in het schoolvak, hoe herkenbaar die ook mogen zijn, blijven enigszins abstract en theoretisch. De consequenties worden concreter zichtbaar als we kijken naar de aansluiting tussen de middelbare school en de universiteit, met name de geesteswetenschappen. Het recente proefschrift van Els van Rooij maakte duidelijk dat leerlingen met maatschappijprofielen minder goed voorbereid worden op de universiteit dan leerlingen met natuurprofielen, en dat zij ook minder goede resultaten halen als ze eenmaal studeren: een leerling met een bètaprofiel doet het in een geesteswetenschappelijke opleiding beter dan een leerling met een maatschappijprofiel, terwijl de profielen juist ontwikkeld zijn om de aansluiting met specifieke vervolgopleidingen te verbeteren. Volgens Van Rooij zit een belangrijk probleem in het feit dat de maatschappijvakken leerlingen onvoldoende zicht bieden op academische praktijk en onvoldoende wetenschappelijke nieuwsgierigheid ('need for cognition') aanwakkeren. ${ }^{3}$ Van Rooij heeft het weliswaar met name over de profielen en dus de vakken die daarin opgenomen zijn, maar voor het verplichte schoolvak Nederlands geldt hetzelfde als voor andere maatschappijvakken: het schoolvak zou meer moeten doen om leerlingen warm te maken voor spannende vragen en inhoudelijke discussies op het terrein van de Neerlandistiek. Het is misschien wel veelzeggend dat in het huidige curriculum Nederlands domein F ('Oriëntatie op studie en beroep') leeg gelaten is: het schoolvak wordt te weinig beschouwd als de aanloop naar een studie Nederlands en een talenberoep. ${ }^{4}$ Het is ook tekenend dat er in Nederland nauwelijks profielwerkstukken worden geschreven over Nederlandse letterkunde. ${ }^{5}$ Leerlingen moeten het vak leren kennen als een onderzoeksveld, waar discussie leeft, waar uitdaging te vinden is, waar urgente kwesties spelen die alleen via een onderzoekende attitude benaderd kunnen worden.

In Van Rooijs onderzoek vinden we zo empirische ondersteuning voor de wens die Heleen Wientjes en Joris Veenhoven ook al formuleerden in hun 
recente handboek over leren onderzoeken voor docenten: er is een longitudinale en latitudinale leerlijn nodig om een onderzoekende houding bij leerlingen te stimuleren. ${ }^{6}$ Als leren onderzoeken begint in de brugklas en eindigt met het profielwerkstuk, langs een leerweg die vorm wordt gegeven in de breedte van alle schoolvakken, is voor het schoolvak Nederlands een belangrijke taak weggelegd. ${ }^{7}$ Het schoolvak is immers op alle niveaus in alle jaren verplicht, en wellicht belangrijker nog: onderzoekende vaardigheden zijn nauw verbonden met het kritisch en precies kunnen lezen en schrijven in het Nederlands.

Er is momenteel in Nederland breed aandacht voor vernieuwing van het curriculum van het schoolvak. Vanuit de universiteiten heeft het Meesterschapsteam Nederlands een voorzet gedaan waarin onderzoeksvaardigheden expliciet worden genoemd en waarin bovendien gepleit wordt voor meer vakinhoud. ${ }^{8}$ Hoe dat er in de praktijk uit kan zien, kunnen we niet alleen aflezen aan de notitie van het Meesterschapsteam, maar ook aan discussies rond het schoolvak Geschiedenis. In die discussies wordt gepleit voor een multiperspectivistische benadering van de geschiedenis: in die benadering ontdekt de leerling dat er verschillende visies bestaan op een historische gebeurtenis, en dat het denken over die gebeurtenis zich in de loop van de tijd heeft ontwikkeld. ${ }^{9}$

Zo'n multiperspectivistische en onderzoekende houding ten aanzien van vakinhoud is in het literatuuronderwijs bij Nederlands hard nodig. ${ }^{10}$ In bestaande literatuurgeschiedenismethoden leren leerlingen de geschiedenis eerder kennen als een rij feiten en begrippen dan als een kennisgebiedin-ontwikkeling dat je op verschillende manieren kunt benaderen. In het literatuuronderwijs ligt het accent op smaakontwikkeling en 'herkennend lezen'. Ook daar ontbreekt een multiperspectivistische insteek. 'Kritisch lezen' leer je pas in het hoger onderwijs, volgens het in 2014 ingevoerde referentiekader.

\section{Tabel 1 Overzicht referentieniveaus}

\begin{tabular}{lll}
\hline Niveau & Drempel naar... & Doel \\
\hline 1 & het voortgezet onderwijs & Kan jeugdliteratuur belevend lezen \\
2 & $\begin{array}{l}\text { de bovenbouw havo en vwo, en het } \\
\text { mbo (tevens algemeen maatschappelijk } \\
\text { basisniveau voor iedere burger) } \\
\text { het hoger beroepsonderwijs }\end{array}$ & $\begin{array}{l}\text { Kan eenvoudige adolescenten- } \\
\text { literatuur herkennend lezen }\end{array}$ \\
3 & & Kan adolescentenliteratuur en \\
& het wetenschappelijk onderwijs & $\begin{array}{l}\text { kritisch en reflecterend lezen } \\
\text { Kan volwassenenliteratuur }\end{array}$ \\
& & interpreterend en esthetisch lezen \\
\hline
\end{tabular}

Overgenomen uit Witte, Mantingh en Van Herten 2017, 125 
Voor een onderzoekende houding is echter nodig dat die persoonlijke waarneming geproblematiseerd wordt. Een onderzoekende lezer is iemand die literatuur benadert als een problematisch en meerduidig construct dat interpretatie behoeft, en inziet dat zo'n interpretatie niet hetzelfde is als 'maar een mening."1 De GNL, mits aangeboden in een toegankelijke vorm, biedt hier kansen. Die serie geeft immers een stand van zaken van het onderzoek, met ook aandacht voor de voortgang van dat onderzoek, de verschillende perspectieven waartoe teksten uitnodigen, de open vragen die er nog zijn. Die eigenschappen kunnen helpen een 'need for cognition' aan te wakkeren.

In deze bijdrage willen we betogen dat een aangepaste versie van de $G N L$ in combinatie met LitLab - een digitaal laboratorium voor literatuuronderzoek voor middelbare scholieren - in het schoolvak Nederlands ingezet kan worden om de onderzoeksattitude van leerlingen te ontwikkelen, om zo de dikwijls betreurde kloof tussen wetenschap en onderwijs verder te dichten. ${ }^{12}$ We schetsen hoe leerlingen in de leeromgeving LitLab getraind kunnen worden als letterkundig onderzoeker, en hoe de GNL daarin kan gaan functioneren. We richten ons daarbij allereerst en met name op de 'proeven' die in LitLab worden aangeboden, en waarin 'leren onderzoeken' wordt gekoppeld aan de verschillende onderdelen van het schoolvakdomein Literatuur: leerlingen trainen hun literaire competentie door tekstfragmenten te lezen en analyseren, breiden hun literair-analytisch en -theoretisch begrippenkader uit, en maken kennis met verschillende periodes en onderwerpen uit de literatuurgeschiedenis. In het vervolg van dit artikel komt ook de profielwerkstukhandleiding van LitLab ter sprake, en tot slot het 'veldwerk' dat LitLab aanbiedt om docenten-in-opleiding letterkundige onderzoeksvaardigheden bij te brengen. De in 2018 gepubliceerde werkvorm LitLab Leesclub laten we in dit artikel buiten beschouwing, omdat de werkvorm in ontwikkeling is en nog weinig getest. ${ }^{13}$ We hebben zowel aandacht voor de didactische uitgangspunten van LitLab als voor de concrete mogelijkheden voor de $G N L$ binnen de verschillende leeromgevingen. Tot slot bespreken we hoe uitgevers, auteurs, onderzoekers en middelbare schooldocenten samen zouden kunnen werken om zover te komen.

Dit artikel richt zich primair op de situatie in het literatuuronderwijs in Nederland, zoals LitLab tot nu toe ook voornamelijk gebruikt en getest is op Nederlandse middelbare scholen. Dat neemt niet weg dat in het Vlaamse middelbaar onderwijs vergelijkbare behoeften en lacunes bestaan. De eindtermen voor het onderdeel Literatuur voor de derde graad (vijfde en zesde jaar) van het Algemeen Secundair Onderwijs (ASO) zijn weliswaar uitgebreider beschreven dan in Nederland, en deze eindtermen maken ook 
het doel expliciet dat leerlingen 'vanuit een tekstervarende en tekstbestuderende manier van lezen literaire teksten uit heden en verleden interpreteren, analyseren en evalueren, ${ }^{14}$ maar dat betekent niet automatisch dat een onderzoekende attitude of een wetenschappelijke literatuurbeschouwing als doel nagestreefd wordt in het huidige curriculum. In Vlaanderen is de geplande herziening van de twintig jaar oude onderwijsdoelen opgenomen in het regeerakkoord 2014-2019 en bereikte het parlement op 16 oktober 2017 overeenstemming over een zestiental competenties die daarin leidend zouden moeten zijn. ${ }^{15}$ Een van die competenties is omschreven als 'leercompetenties met inbegrip van onderzoekscompetenties [etc.]'16 De LitLab-redactie hoopt dat LitLab ook in het Vlaamse onderwijs een instrument kan zijn om deze vernieuwde doelen te bereiken.

\section{LitLab: didactische uitgangspunten}

Het digitaal laboratorium LitLab (www.litlab.nl) is ontwikkeld aan de Universiteit Utrecht om leerlingen te trainen in het doen van letterkundig onderzoek. Met LitLab - de term verwijst zowel naar het digitale laboratorium dat we klaar hebben staan als naar het laboratorium dat de literatuur kan zijn als leeromgeving - kunnen leerlingen proefondervindelijk kennis maken met de complexiteit van literatuur en de rol van literatuur in de Nederlandse samenleving. LitLab faciliteert zo het 'leren onderzoeken'. Daaronder verstaan we zowel het leren hoe wetenschappelijk onderzoek wordt gedaan, als het leren hoe je zelf dit soort onderzoek kunt doen. ${ }^{17} \mathrm{Om}$ die doelen te bereiken, zijn concrete onderzoeksvaardigheden nodig, zoals het kunnen formuleren van een vraag. Maar even belangrijk - en vaak over het hoofd gezien - is de 'onderzoekende houding': een onderzoeker moet nieuwsgierig en kritisch zijn, over onderzoeksresultaten kunnen rapporteren en in dialoog treden met voorgangers. ${ }^{18}$

Omdat grootschalig onderzoek naar de notie van leren onderzoeken binnen het literatuuronderwijs vooralsnog ontbreekt, is LitLab een poging om al doende passende vakdidactiek te ontwikkelen vanuit bestaande didactische inzichten en praktijken bij andere schoolvakken. Met name in de exacte vakken - scheikunde, natuurkunde, biologie - staan onderzoeksvaardigheden hoog in het vaandel. Ze worden sinds jaar en dag getraind via practica, ${ }^{19}$ die alleen maar belangrijker werden toen de onderzoeksvaardigheden werden opgenomen in de examenprogramma's van de Tweede Fase. Dat practicumonderwijs is zeker niet verheven boven elke kritiek: het grote accent op zelfstandig werken zou het leren van onderzoeksmatig denken 
in de weg zitten, ${ }^{20}$ en te vaak zou worden teruggegrepen op zogenaamde 'kookboekpractica' met een voorgeschreven recept, zodat leerlingen wel oefenen met het uitvoeren van onderzoek, maar niet met de complexe metacognitieve vaardigheden die het opzetten en evalueren van onderzoek vereisen. ${ }^{21}$ Concreet betekent dat bijvoorbeeld dat leerlingen bij scheikunde een toegepaste vorm van wetenschap (met een probleemstelling die exact beantwoordbaar is) voorgelegd krijgen waarbij onderliggende paradigmatische kwesties niet aan de orde komen. Maar het vakdidactische onderzoek dat er - met name in die beginjaren van de Tweede Fase - is verricht naar onderzoek binnen de exacte vakken bevat nuttige aanbevelingen en inzichten die ons helpen om een didactiek van leren onderzoeken voor het literatuuronderwijs te ontwikkelen. Bovendien kunnen we putten uit studies over het leren onderzoeken en onderzoekend denken in andere schoolvakken: aardrijkskunde, economie en - met name - geschiedenis. ${ }^{22}$

Uit het bestaande onderzoek zijn enkele factoren te destilleren die het leren onderzoeken lijken te bevorderen, en die wij hebben gebruikt bij de ontwikkeling van een didactisch model voor LitLab. Van Rens en Van Veenhoven raden aan om onderzoeksvaardigheden te trainen via een didactiek van 'onderzoekend leren': ${ }^{23}$ een actieve, zelfregulerende, constructivistische manier van leren, waarbij de leerling zelf de regie neemt. ${ }^{24}$ Leren onderzoeken en onderzoekend leren kunnen volgens Van Rens het beste samenkomen in een onderwijsontwerp waarbij leerlingen een stapsgewijs onderzoeksproces doorlopen dat cyclisch en iteratief van karakter is. ${ }^{25}$ Naar analogie van de empirische cyclus van waarnemen - vermoeden verwachten - toetsen - evalueren die in exacte vakken gebruikt wordt, definiëren Wientjes en Veenhoven een geesteswetenschappelijke cyclus van reflectie: ${ }^{26}$

- opmerkzame waarneming doen (iets lezen);

- nieuwsgierigheid volgen: hoe zou dat zitten, zou dit kunnen betekenen dat, hoe verhoudt dit zich tot bronnen die we eerder lazen? etc.;

- zorgvuldige analyse, interpretatie en overdenking van het gelezene maken: in vergelijking met andere bronnen of bestaande analyses en interpretaties;

- een welberedeneerde conclusie trekken.

In het geschiedenisonderwijs beoogt men zo'n onderzoekscyclus in gang te zetten om een oplossing te vinden voor wat wel 'ondergestructureerde problemen' worden genoemd: problemen die niet met zekerheid op één manier opgelost kunnen worden, maar multi-interpretabel zijn. ${ }^{27}$ Die 
problemen moeten de jonge onderzoekers uitnodigen tot een proces van kennistransformatie: leerlingen worden uitgedaagd om verbanden te leggen en te redeneren, met als doel een eigen conclusie te vormen en kunnen verdedigen. ${ }^{28}$

Zowel in het schoolvak geschiedenis als in de vakken in de bèta- en gammahoek wordt aangenomen dat de didactiek van het leren onderzoeken staat of valt bij een vruchtbare interactie met docent en medeleerlingen. Complexe opdrachten vragen feedback en sturing, ${ }^{29}$ terwijl er tegelijkertijd voldoende openheid nodig is om een proces van wetenschappelijk redeneren ruimte te geven. ${ }^{30}$ Hubers stelt het zich ideaal voor als een 'cognitive apprenticeship'-model waarbij leerlingen van hun leermeester leren door good practices te observeren, en langzaam meer vrijheid krijgen, waarin zij steeds complexere en meer diverse onderzoeksactiviteiten kunnen ontplooien. ${ }^{31}$ De rol van de leermeester is daarbij geen eenvoudige: het demonstreren en begeleiden van een onderzoeksproces met ongewisse uitkomsten vraagt om een docent die zelfverzekerd kan opereren (de zogenaamde 'zekerheidsparadox'). ${ }^{32}$ In een onderwijspraktijk waarin steeds meer docenten zelf geen universitaire opleiding hebben genoten, is die expertise en attitude van docenten niet vanzelfsprekend.

Een digitale leeromgeving kan voor een deel deze complexe taak van de leermeester overnemen: de leerling krijgt een stapsgewijze structuur aangeboden, kijkt goede voorbeelden af en krijgt daarna de ruimte om eigen paden te verkennen. Zowel de uitwisseling met medeleerlingen als het op eigen niveau werken kunnen via een digitaal leerinstrument worden gefaciliteerd. ${ }^{33}$

Op basis van eerdere onderzoeksresultaten en aanbevelingen ten aanzien van het leren onderzoeken kunnen we dus verwachten dat een digitale leeromgeving leerlingen kan begeleiden in de ontwikkeling tot jonge literatuuronderzoekers. Daarvoor is het nodig dat een stapsgewijze cyclische onderzoekstructuur wordt aangeboden waarin leerlingen multi-interpretabele vraagstukken al redenerend kunnen oplossen. Daarbij moeten ze gestuurd worden maar ook zelfstandig kunnen werken, en gebruik kunnen maken van algemene onderzoeksvaardigheden en een onderzoekende houding die ze ook al bij andere schoolvakken aanleerden. Het ontwerp van LitLab is gebaseerd op deze succesfactoren. 


\section{LitLab Proeven: ontwerp en mogelijkheden voor de $G N L$}

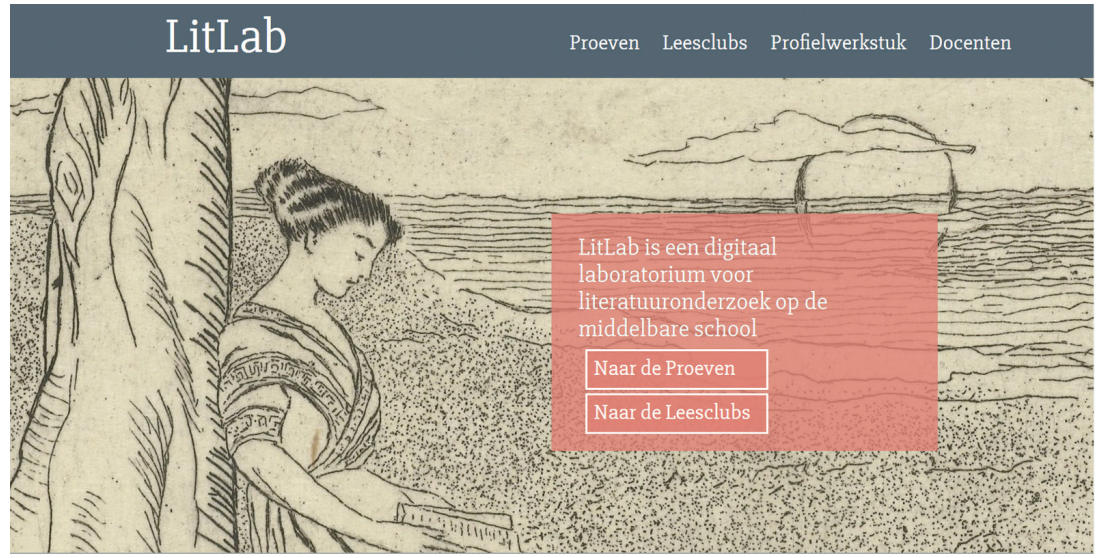

Afbeelding 1 Screenshot openingspagina LitLab

Binnen LitLab hebben we 'proeven' ontwikkeld voor leerlingen uit de bovenbouw havo-vwo, die in twee tot drie lesuren te doorlopen zijn. We gaan ervan uit dat de leerlingen beginnende literatuuronderzoekers zijn, en bieden hen zoveel mogelijk steun om uiteindelijk zelfstandig een ongestructureerd probleem aan te pakken. De aangesneden problemen hebben te maken met centrale vragen. Hoe functioneert literatuur in een (historische) samenleving? Hoe 'werken' literaire teksten, bijvoorbeeld in vergelijking tot zakelijke tekstgenres? Met welke specifieke problemen krijg je te maken als literatuuronderzoeker? De vragen formuleren we zelf en ook bijpassende theoretische termen worden aangeleverd: de proeven focussen dus op het aanleren van een specifiek deel van de onderzoekscyclus, met name het analyseren, interpreteren en concluderen. Elke proef bestaat uit vijf stappen, die hieronder weergegeven zijn.

Hoe ziet het leerproces er in een proef uit? We nemen hieronder twee proeven als voorbeeld, waarna we schetsen hoe deze proeven met concrete delen uit de GNL geïntegreerd kunnen worden.

De eerste proef stelt als centrale vraag: 'Wat is literatuur?' In stap 1 wordt uitgelegd dat er twee verschillende onderzoekstradities zijn als het gaat om het beantwoorden van die vraag. De ene onderzoekstraditie gaat ervanuit dat het antwoord op de vraag 'wat is literatuur?' besloten ligt in kenmerken van de tekst zelf. We leggen uit dat analyseren op structuurkenmerken, 
Een inleiding in de materie door middel van concrete voorbeelden waarbij aangesloten wordt op de voorkennis. Het centrale vraagstuk wordt gepresenteerd. Aan het eind van stap 1 staan enkele vragen die leerlingen helpen de gegeven voorbeelden verder te verkennen en te doorgronden.

\section{昷}

Stap 2: De instrumenten (begrijpen)

De introductie van nieuwe begrippen of concepten die gaan dienen als onderzoeksinstrumenten, met een uitleg hoe deze concepten tot een antwoord op de in stap 1 geïntroduceerde onderzoeksvragen kunnen leiden. Aan het eind worden begripsvragen gesteld.

\section{每}

Stap 3: Het experiment (testen en/of analyseren)

Een introductie op de digitale tool of het materiaal en een instructie voor het gebruik ervan. De opdrachten in deze stap laten de leerlingen experimenteren met de tool of het materiaal en laat ze verbanden leggen met de vragen uit de vorige twee stappen.

\section{咀}

Stap 4: De lakmoesproef (reflecteren/terugkoppelen)

Tijdens deze stap wordt de vorige stap geëvalueerd door middel van een grotere opdracht met meer eigen inbreng. Wat zeggen de resultaten? Zijn er conclusies te trekken? Argumentatie speelt in deze stap een belangrijke rol.

\footnotetext{
具 Stap 5: Het vrije experiment (verdiepen)

In de laatste stap krijgen leerlingen meer vrijheid en ruimte om te reflecteren op het gebruik van de tool en tot meer diepgang in de materie te komen. Leerlingen kunnen in deze stap bijvoorbeeld naar eigen inzicht verder experimenteren en daarover schrijven, debatteren over gerelateerde onderwerpen of creatief schrijven.
}

\section{Afbeelding 2 De stapsgewijze opzet van een proef}

zoals leerlingen zelf hebben leren doen, in die traditie past. De andere onderzoekstraditie kijkt naar contextuele factoren (instituties als uitgeverijen, het Nobelcomité maar ook de leraar Nederlands). Leerlingen maken zelf een lijstje van hun eigen criteria. In stap 2 wordt Bourdieus theorie van het literaire veld geïntroduceerd als (toonaangevend) voorbeeld van een theorie uit de tweede onderzoekstraditie. Leerlingen bekijken hun criteria uit stap 1 nogmaals om te zien welke daarvan binnen dat theoretisch kader vallen. In stap 3 bekijken ze recent, kwantitatief onderzoek naar de vraag 'wat is literatuur?'. Ze beoordelen dat door in opdrachten kritisch te kijken naar de resultaten en uitwerking van dat onderzoek. In stap 4 krijgen ze de opdracht om te reageren op een stelling als 'Het is onmogelijk om objectieve maatstaven te vinden voor de beoordeling van literaire teksten (bijvoorbeeld voor recensenten) en dat moeten we dan ook niet proberen'. In stap 5 wordt hun opnieuw gevraagd naar een bestaand onderzoek te kijken, in dit geval het boek The Bestseller Code van Matthew Jockers en Jodie Archer, 
twee literatuurwetenschappers die beweren een algoritme te hebben ontwikkeld waarmee met een nauwkeurigheid van 8 o procent voorspeld kan worden of een roman een bestseller wordt of niet. Ook dit onderzoek gaan leerlingen kritisch bestuderen, maar nu meer op eigen kracht (dus zonder opdrachten die hen stap voor stap geleiden), met als einddoel dat onderzoek te plaatsen binnen de twee onderzoekstradities uit stap 1.

De tweede proef die we als voorbeeld nemen stelt als centrale vraag: 'Hoe schreven Nederlanders over slavernij?' In deze proef maken leerlingen kennis met reacties in het discours over slavernij van de zeventiende tot de twintigste eeuw. Stap 1 schetst beknopt een historische context over slavernij en slavenhandel in Nederland en maakt duidelijk waarom teksten over slavernij een interessante bron vormen voor literatuuronderzoek: teksten kunnen een discours bevestigen, maar ook veranderen. Die bevestigende functie van literaire teksten wordt vervolgens geillustreerd in een gedicht van Jacob Cats. Stap 2 introduceert de analytische termen 'discours' en 'de Ander' en laat leerlingen die termen toepassen op de Afrikaanse brieven van Willem Godschalck van Focquenbroch. In stap 3 wordt vervolgens meer in detail het discours rond slavernij onderzocht in opnieuw een nieuwe tekst, ditmaal uit de achttiende eeuw: Geschiedenis van een neger, zijn reize met de Heer N.... van Surinamen naar Holland (1771). Stap 4 verdiept die analyse door middel van een gespreksopdracht waarin leerlingen in groepjes discussiëren over de bevestigende of kritische functie van Geschiedenis van een neger. Stap 5 veronderstelt dat de leerlingen nu voldoende in staat zijn om zelfstandig onderzoek te doen naar dit thema. Ze kiezen een tekst uit de negentiende of twintigste eeuw en schrijven een essay over de plaats van die tekst binnen het discours zoals ze dat tot nu toe diachroon onderzocht hebben. Ze kunnen kiezen uit een Nederlandse vertaling van Uncle Tom's Cabin (1853), het pamflet De slavernij in Suriname (1853) dat op die roman reageert, of de tekst Wij slaven van Suriname van Anton de Kom (1932).

Of de proeven hun doel bereiken is nog niet systematisch vastgesteld en we onderschrijven de wens van Witte, Mantingh en Van Herten naar een empirisch onderzoek naar de leereffecten van een middel als LitLab. ${ }^{34}$ Kwalitatieve evaluatie heeft niettemin veelvuldig plaatsgevonden sinds de eerste versie van LitLab werd opgeleverd in oktober 2016. We hebben evaluaties en gastlessen georganiseerd met vijftien vwo4-, vwo5- en vwo6klassen van zes verschillende scholen. ${ }^{35}$ Daarnaast hebben we op basis van feedback van leerlingen het ontwerp geëvalueerd en waar nodig verandering aangebracht. Leerlingen waardeerden de stapsgewijze, cyclische structuur met een balans tussen zelfstandigheid en sturing. Zo werden als positieve punten genoemd: 'Interactief, veel open vragen waarbij je zelf moest 
nadenken', 'Je bent zelf met het onderwerp bezig en leert ook', 'Leuk dat je zelf mag kijken in bijv. de Ngram Viewer en dat je dus zelf mag onderzoeken', 'De methode liet je zelf dingen onderzoeken', 'Dingen leren door het zelf uit te zoeken (Wordcloud)' etc. Negatief waren de leerlingen over de lengte van de instructieteksten (te lang); om die reden zijn ze ingekort, en is het taalgebruik her en der aangepast om gemakkelijker doorlezen mogelijk te maken. Ook op basis van workshops met verschillende docenten Nederlands zijn aanpassingen gedaan. Zo hebben we op advies van docenten meer momenten ingeruimd waarop het onderzoeksproces tussentijds geëvalueerd wordt, bijvoorbeeld klassikaal, in de vorm van speeddates of in gesprek met de docent.

$\mathrm{Na}$ aanpassing van de eerste versie hebben we een tweede evaluatie gebruikt om middels een gesprek met de leerlingen een indruk te krijgen van wat vwo5-leerlingen al weten van onderzoek doen en welke associaties zij daarbij hebben. Deze brainstorm activeerde de kennis van de leerlingen zoals ze die opgedaan hadden bij andere vakken: ze benoemden verschillende stappen uit een mogelijke onderzoekscyclus, zoals 'vraag', 'hypothese', 'onderzoeksplan', 'waarnemingen doen', 'informatie verzamelen', 'resultaten', 'conclusie', 'discussie'. Tijdens de discussie die we na afloop van het werken met LitLab met de leerlingen hielden, koppelden de leerlingen vervolgens terug op die onderzoekscyclus en vergeleken zij LitLab met de vormen van onderzoek die zij in andere vakken al tegengekomen waren. Leerlingen vonden het type onderzoek van LitLab ten dele herkenbaar, maar zagen ook belangrijke verschillen. Zo werd genoemd dat er bij LitLab geen sprake is van een (expliciete) hypothese, of dat scheikundig onderzoek meer om feiten en natuurwetten draait. Een ander methodologisch verschil dat leerlingen opmerken, was dat scheikunde vaste procedures vereist waarin de afzonderlijke onderzoekstappen meer van elkaar afhankelijk zijn, terwijl in LitLab die stappen groter zijn en minder strikt van elkaar gescheiden. Ook vond een leerling dat er bij letterkundig onderzoek meer sprake was van interpretatie, een aspect dat volgens haar afwezig is bij scheikunde. Een andere leerling stelde dat hij geen van de stappen uit bovengenoemde onderzoekscyclus terugzag bij LitLab en dat er dus een groot verschil is met letterkundig onderzoek. Aan de andere kant zagen enkele leerlingen een sterke gelijkenis met het type bronnenonderzoek dat het vak geschiedenis van hen vraagt.

De meeste leerlingen leken dus intuïtief overeenkomsten en verschillen tussen verschillende vormen van onderzoek (natuur- versus geesteswetenschappelijk, of nomothetisch versus idiografisch) te kunnen herkennen vanuit hun achtergrondkennis van andere vakken en de 
onderzoeksvaardigheden die ze daar al opdeden. Dat bij het vak scheikunde gewerkt wordt met vraagstellingen die exact te beantwoorden zijn, waardoor discussies rond interpretaties van resultaten uitblijven, verklaart het verschil dat een leerling waarneemt tussen dat vak en LitLab. Uit die vergelijking en de overige evaluaties blijkt dus dat veel leerlingen profiteren van de achtergrondkennis vanuit andere vakken als ze met LitLab werken, maar ook in staat zijn verschillen met een meer geesteswetenschappelijke vorm van onderzoek te herkennen als ze daartoe aangezet worden. Ook lijken ze de interactieve vorm en de mate van zelfstandig onderzoeken die LitLab stimuleert te herkennen en waarderen. Maar een enkele leerling zag geen verband tussen onderzoek bij andere vakken en LitLab. We moeten dit soort onderwijsgesprekken vaker voeren om te zien voor hoeveel leerlingen dit het geval is, en - mochten dat er veel zijn - nog explicietere aanknopingspunten aanreiken om voor leerlingen vergelijken mogelijk te maken.

Hoe kan LitLab met inzet van de GNL nog effectiever worden? We zien mogelijkheden om LitLab te combineren met fragmenten uit de GNL om zo een concreet middel aan te bieden waarmee leerlingen tegelijkertijd een onderzoekende attitude aanleren en vakinhoudelijke kennis over de Nederlandse literatuurgeschiedenis verwerven. Dat kan door leerlingen ter voorbereiding op de proef gerichte fragmenten uit de $G N L$ te laten lezen die het materiaal in de proeven kunnen contextualiseren. In het geval van de eerste proef kunnen leerlingen bijvoorbeeld ontdekken dat een tekstgerichte poëtica en letterkunde gevormd zijn in dialoog met literatuurkritische debatten rond Forum, ${ }^{36}$ Podium en Merlyn. ${ }^{37}$ De passages in de literatuurgeschiedenis laten duidelijk zien dat ideeën over de relatie tussen tekst en literaire kwaliteit veranderen, maar ook dat daarover tussen tijdgenoten onderling nooit consensus bestaan heeft. In het geval van de tweede proef kunnen leerlingen zich een beeld vormen van wat Focquenbroch voor dichter was, en hoe diens (burleske) reputatie mogelijk doorwerkt in de manier waarop hij zich in het discours over de Afrikaanse Ander mengt; ${ }^{38}$ of zien hoe de roman Geschiedenis van een neger, zijn reize met de Heer N.... van Surinamen naar Holland past in de ontwikkeling van de roman als serieus genre; ${ }^{39}$ of leren hoe de verwijzing naar Uncle Tom's Cabin tijdens de jaren 1930 doorwerkte in de receptie van De Koms Wij slaven van Suriname. ${ }^{40}$ Daarbij zijn er uiteraard andere verwerkingsopdrachten denkbaar - zo kunnen leerlingen ook ná een proef de literatuurgeschiedenis lezen om vanuit de aangeleerde invalshoek een onderzoeksvraag te formuleren over de literatuurhistorische periode in kwestie. 


\section{$4 \quad$ LitLab Profielwerkstukhandleiding: ontwerp en mogelijkheden voor de $G N L$}

Ook de begeleiding bij het schrijven van een Profielwerkstuk (verder: PWS) is binnen LitLab stapsgewijs opgezet. Deze begeleiding wordt aangeboden via een digitale handleiding die beschikbaar is op de site van LitLab. ${ }^{41}$ Voor leerlingen die nog niet vertrouwd zijn met letterkundig onderzoek, is er een inleiding die in feite samenvat wat er ook in de proeven geleerd wordt: je hebt een vraag nodig, een onderzoekskader, een methode en bronnen. Wie aan zijn PWS wil beginnen, krijgt binnen LitLab hulp bij de verschillende onderzoeksstappen:
stap 1: oriëntatie en vaststellen onderzoeksvraag;
stap 2: zoeken van bronnen, opzetten van onderzoek;
stap 3: onderzoeksgegevens verzamelen;
stap 4: onderzoeksgegevens uitwerken;
stap 5: onderzoek presenteren.

In stap 1 worden voor vier grote thema's (literatuur \& media; literatuur \& identiteit; literatuur \& maatschappij; literatuur \& kwaliteitscriteria) voor in totaal zo'n 35 onderzoeksgebieden globale vraagstellingen aangereikt die de leerlingen in stap 2 kunnen preciseren aan de hand van aanvullende informatie: samenvattingen van vakdiscussies, suggesties voor het gebruik van bepaalde theorieën en suggesties voor inperking van de vraag of combineren van een vraag naar Nederlandse letterkunde met vragen uit een ander vakgebied (een andere schooltaal, of een vak als economie of informatica). In stap 3 worden ze begeleid in het kiezen van een kwantitatieve dan wel kwalitatieve onderzoeksaanpak en leren ze een onderzoek volgens een van beide methoden op te zetten. In stap 4 krijgen ze hulp bij het verwerken en opschrijven van hun analyses. Voor stap 5, de presentatie van de resultaten, verwijst de site naar richtlijnen die elke individuele school voor de verslaglegging van het PWS geeft. Zo kan een leerling via het grote thema 'literatuur \& media' onderzoek gaan doen naar auteurs en promotieactiviteiten in de media. Er worden recente debatten rond dat onderwerp aangereikt en besproken, en voorbeelden gegeven van hoe zoiets met een kwalitatieve methode te onderzoeken is. Via het grote thema literatuur \& kwaliteitscriteria' loopt zo'n spoor dan weer heel anders: daar wordt een leerling gewezen op de mogelijkheid kwantitatief onderzoek te doen naar criteria die op een site als mustread.nl gebruikt worden, en dienen enkele recente artikelen als voorbeeld van de aanpak in dergelijk onderzoek. 
Gebruik van de GNL zou met name voor stap 1 (het vinden van een vraag) en stap 2 (en dan met name: het vaststellen van de status quo in het onderzoek waar die vraag bij hoort) zeer wenselijk en nuttig zijn. Momenteel wordt op de LitLab-site op die plek verwezen naar artikelen die online en Open Access beschikbaar zijn. Dat geeft een ongewenste inperking. Veel beter zou het zijn ook naar een overzichtspassage uit een van de GNL-delen te kunnen wijzen, zodat de leerlingen de brede blik op een bepaald deel van het onderzoeksgebied niet uit een samenvatting van LitLab maar uit eerste hand kunnen verkrijgen.

\section{$5 \quad$ LitLab Veldwerk: ontwerp en mogelijkheden voor de GNL}

Naast de proeven en de PWS-handleiding heeft LitLab 'Veldwerk' ontwikkeld, in samenwerking met de Open Universiteit en mede gefinancierd door het Duurzame Geesteswetenschappen project 'Meer academisch geschoolde leraren voor de klas'. Omdat dit gedeelte van LitLab zich in de pilotfase bevindt, is het momenteel nog niet openbaar toegankelijk, maar dat zal in de nabije toekomst veranderen.

LitLab Veldwerk is bedoeld voor tweedegraadsdocenten die via een premaster een eerstegraads bevoegdheid aan de universiteit willen behalen. Deze docenten-in-opleiding hebben niet alleen een kennislacune op het gebied van de literatuurgeschiedenis, maar ook een gebrek aan ervaring en oefening in academische onderzoeksvaardigheden. Recent onderzoek van zowel Els van Rooij als Björn Wansink maakte duidelijk dat een onderzoekende aanpak in de klas zeer sterk afhankelijk is van de bekwaamheid van de docent: die moet bekend zijn met zo'n multiperspectivistische aanpak en zich vertrouwd voelen op zijn onderzoeksterrein. Op dit moment is de beweging eerder om docenten van de literatuurgeschiedenis af te houdenzie de discussies over het aandeel literatuurgeschiedenis in het curriculum van tweedegraadsdocenten ${ }^{42}$ - maar wij proberen met LitLab Veldwerk juist materiaal te ontwikkelen om de onderzoekende vaardigheden van docenten te trainen, zodat zij in hun toekomstige onderwijs het literatuuronderzoek een plaats kunnen geven.

Met LitLab Veldwerk worden de docenten-in-opleiding geoefend in het doen van transhistorisch onderzoek op het gebied van een actueel thema in de Nederlandse letterkundestudie: zij leren stapsgewijs een onderzoeksmethode aan, proberen die uit, en ronden het Veldwerk af met een eigen onderzoek $(\mathrm{je})$ binnen het themaveld. Het Veldwerk is in vergelijking met 
Proeven veeleisender, omdat het meer gericht is op een veld overzien en daar zelf een onderzoekje in gaan doen. Voor dat onderzoek worden ook literatuurtips gegeven, maar de grote handicap daarbij is de toegankelijkheid van materiaal. De GNL kan dus hier een belangrijke functie vervullen in het ontsluiten van het onderzoeksveld van de Nederlandse letterkunde. Mogelijk moeten we hier ook nog wat verder gaan, en leeswijzers bij passages uit de delen van de GNL aanbieden (zoals Nederlandse literatuur, een studiehandleiding dat ooit deed bij Nederlandse literatuur, een geschiedenis ). ${ }^{43}$

\section{Wensen voor de toekomst}

We hebben in dit artikel betoogd dat het in sommige opzichten nog aan de didactische voorwaarden ontbreekt om de nieuwste literatuurgeschiedenis zinvol te kunnen integreren in het huidige curriculum. LitLab voorziet deels in het creëren van die voorwaarden: het laboratorium biedt een cyclische didactiek waarin leerlingen leren onderzoeken en waarin de mogelijkheden van het digitale platform benut worden. Daarnaast vormt LitLab een praktische schakel tussen onderzoek en onderwijs waarvan beide partijen kunnen profiteren: we begeleiden en raadplegen docenten door middel van workshops, scholenbezoek, een antwoordmodel en een uitgebreide handleiding voor profielwerkstukken. Maar er rest nog een aantal voorwaarden die noodzakelijk zijn om de literatuurgeschiedenis op de geschetste wijze te kunnen aanbieden. We besluiten daarom met een aantal wensen of aanbevelingen, gericht aan de Taalunie, de auteurs en de uitgever van de literatuurgeschiedenis:

1 Er moeten onderwijsmaterialen komen die de instap mogelijk maakt voor docenten die niet-academisch geschoold zijn maar toch over academisch onderzoek willen doceren. Naast LitLab Veldwerk, zouden dat een studiehandleiding/leeswijzer bij delen van de GNL kunnen zijn. Die leeswijzer maken is nog een ingewikkelde kwestie. Hij zou er voor elke werkvorm wel eens anders uit moeten zien, zo kunnen we aan de hand van LitLab constateren. Voor de proeven zal iets anders nodig zijn dan voor de profielwerkstukken. In beide gevallen zal de $G N L$ sterk aangepast moeten worden, en zal ook per deel van de GNL naar oplossingen moeten worden gezocht om leerlingen te helpen informatie uit de GNL-teksten te halen. Geen deel is immers hetzelfde. Basis is wellicht dat zo'n leeswijzer bestaat uit tips over hoofdstukken/paragrafen die leerlingen kunnen raadplegen voor hun onderzoek, met daarbij 
verwerkingsvragen die hen in staat stellen te zien of ze essentiële informatie opgepikt hebben.

2 Delen van de GNL zouden Open Access beschikbaar moeten zijn om beter in nascholing voor docenten en onderwijsmaterialen voor leerlingen verwerkt te kunnen worden. In overleg met docenten kan een selectie van fragmenten opgesteld worden, inclusief een opgave van secundaire literatuur die voor die specifieke passages in de GNL gebruikt is.

3 De GNL zou voor docenten volledig toegankelijk moeten worden: het moet voor hen duidelijk zijn hoe de $G N L$ in het onderzoek functioneert, en hoe na de $G N L$ dat onderzoek ook weer verder is gegaan en elke dag aangevuld en verbeterd wordt (o.a. door leerlingen die door de docenten zelf opgeleid worden). Aan de beschikbaar gestelde fragmenten van de GNL zouden dus vervolgvragen en (mogelijk) vervolgonderzoek gekoppeld moeten worden.

4 Behalve voor de proeven is de $G N L$ bijzonder geschikt als inleiding tot een profielwerkstuk. Daarvoor heeft LitLab al materiaal ontwikkeld, maar elke intro zou idealiter beginnen met een fragment $G N L$ waarin een stand van zaken beschreven wordt in de kennis over een bepaalde tekst/ literair fenomeen/ etc.

\section{Noten}

1. http://leerplaninbeeld.slo.nl/examenprogrammas/examenprogramma-nederlands-hv. pdf/

2. Laagland (2011), 56, 67, 135-136.

3. Van Rooij (2018).

4. Zie: http://leerplaninbeeld.slo.nl/examenprogrammas/examenprogramma-nederlandshv.pdf.

5. Deze informatie ontlenen we aan gesprekken met docenten tijdens gastlessen en met de Stichting Leerplan Ontwikkeling (SLO).

6. Wientjes en Veenhoven (2016).

7. Wientjes en Veenhoven (2016).

8. Meesterschapsteams (2016); Meesterschapsteams (2018).

9. Wansink (2017).

10. https://curriculum.nu/ontwikkelteam/nederlands/.

11. Appleyard (1991).

12. Witte, Mantingh \& Van Herten (2017); Slings (2000).

13. De LitLab Leesclubs bieden een werkvorm met onderwijsmateriaal dat ook leerlingen uit de bovenbouw vmbo en onderbouw havo/vwo een onderzoekende leeshouding aan wil leren door middel van een interactief, digitaal kaartspel met discussievragen over een gelezen tekst (zie Dietz, Van der Deijl en Stronks 2018). Het programma PlusNederlands 
wil leerlingen - over de volle breedte van VMBO tot VWO - stimuleren om vragen te leren stellen over de Nederlandse taal en cultuur, en begeleidt leerlingen in hun zoektocht naar antwoorden op die vragen. Het programma is gë̈nspireerd op stimuleringsinitiatieven van andere schoolvakken, zoals de Olympiades van de bètavakken, de taalcertificaten van de moderne talen en het plusaanbod 'Jong Ondernemen' van het schoolvak economie. PlusNederlands wordt momenteel ontwikkeld aan de Universiteit Utrecht, met medewerking van onder andere de Taalunie, de KNAW, de KANTL, de IVN en de SLO.

14. http://eindtermen.vlaanderen.be/secundair-onderwijs/derde-graad/aso/vakgebonden/ nederlands/eindtermen.htm.

De Vlaamse eindtermen bieden zo al enige ruimte voor een multiperspectivistische en bestuderende of onderzoekende manier van lezen: leerlingen kunnen verbanden leggen 'binnen teksten; tussen teksten; tussen teksten en het brede socioculturele veld; tussen tekst en auteur; tussen teksten en hun multimediale vormgeving'. Verder kunnen ze 'verslag uitbrengen over de eigen ervaringen met literaire teksten uit heden en verleden en kunnen deze ervaringen toetsen aan andere interpretaties van en aan waardeoordelen over teksten'.

15. https://onderwijs.vlaanderen.be/nl/modernisering-secundair-onderwijs-en-nieuweeindtermen-in-laatste-rechte-lijn.

16. 'Voorstel van Decreet houdende wijziging van het decreet basisonderwijs van 25 februari 1997 en de Codex Secundair Onderwijs, wat de onderwijsdoelen betreft'. Ingediend op 9 november 2017. Vlaams Parlement doc. 1364 (2017-2018) nr. 1.

17. Vergelijk Van Rens en Dekkers (2000); Van Veenhoven (2004).

18. Aarsen en Van der Valk (2008); Wientjes en Veenhoven (2016).

19. Lock (1988).

20. Smits (2003).

21. Hubers (2003).

22. Van Veenhoven (2004); Rijborz (2003); Wansink (2017); Voet \& De Wever (2017); Van Drie \& Van Boxtel (2008).

23. Van Rens (2004); Van Veenhoven (2005).

24. Ebbens en Ettekoven (2013); Hubers (2003).

25. Van Rens (2005).

26. Wientjes en Veenhoven (2016), 37.

27. Voet \& De Wever (2017); Wansink (2017).

28. Voet \& De Wever (2017).

29. Van Rens (2005).

30. Roth (1994).

31. Hubers (2003).

32. Wansink (2017).

33. Van Drie, Van Boxtel \& Van der Linden (2006); Bransford, Brown \& Cocking (2000); Hubers (2003).

34. Witte, Mantingh en Van Herten (2017).

35. Het St. Gregorius College in Utrecht, het Odulphuslyceum in Tilburg, de O.R.S. Lek en Linge in Culemborg, de Werkplaats Kindergemeenschap in Bilthoven, het Montessori Lyceum in Amsterdam en het Leidsche Rijn College in Utrecht.

36. Bel (2008), 651-654.

37. Brems (2006), 144-146; Brems (2006), 240-245.

38. Porteman \& Smits-Veldt (2008), 622-627.

39. Leemans \& Johannes (2013), 354-372.

40. Bel (2015), 839-843. 
41. https://litlab.nl/pws.

42. Zie bijvoorbeeld http://www.neerlandistiek.nl/2018/o4/lerarenopleiders-nederlandsverenigt-u/.

43. Meijer Drees (1993); Schenkeveld \& Anbeek (1993).

\section{Literatuur}

Aarsen, M. \& T. van der Valk, 'Onderzoekende houding, een leerlijn', in: NVOX 33, 2008, 8, 354-357. Appleyard, J.A., Becoming a Reader. The Experience of Fiction from Childhood to Adulthood, Cambridge University Press, Cambridge, 1991.

Bel, J., Bloed en Rozen. Geschiedenis van de Nederlandse literatuur 1900-1945, Bert Bakker, Amsterdam, 2015.

Bransford, J.D., A.L. Brown \& R.R. Cocking, How people learn. Brain, mind, experience, and school, National Academy Press, Washington, 2000.

Brems, H., Altijd weer vogels die nesten beginnen. Geschiedenis van de Nederlandse literatuur 19452005, Bert Bakker, Amsterdam, 2006.

Collins, A., J.S. Brown \& S.E. Newman, 'Cognitive apprenticeship: Teaching the crafts of reading, writing, and mathematics', in: L.B. Resnick (Ed.), Knowing, learning, and instruction: Essays in honor of Robert Glaser, Lawrence Erlbaum Associates, Hillsdale, NJ, 1989, 453-494.

Dietz, F., L. van der Deijl en E. Stronks, 'De LitLab leesclubs: herkennend en onderzoekend lezen in een interactieve gespreksvorm', in: Tweeëndertigste conferentie Onderwijs Nederlands. Gent 2018, 317-321.

Drie, J. van \& C. van Boxtel, 'Historical reasoning: Towards a framework for analyzing students' reasoning about the past', in: Educational Psychology Review 20, 2008, 2, 87-110.

Drie, J. van, C. van Boxtel \& J. van der Linden, 'Historical reasoning in a computer-supported collaborative learning environment', in: H.M. O'Donnell e.a., Collaborative learning, reasoning and technology, Erlbaum, Mawhah, NJ, 2006, 265-296.

Ebbens, S., \& S. Ettekoven, Effectief leren, Noordhoff Uitgevers, Groningen/Houten, 2013.

Hubers, S., Individuele leertheorieën en het leren onderzoeken in de Tweede Fase, dissertatie Technische Universiteit Eindhoven, 2003.

KNAW, Academisch gevormde leraren in het voortgezet onderwijs. Position paper, KNAW, Amsterdam, 2017 .

Laagland, literatuur en lezer, Thieme Meulenhoff, Amersfoort, 2011.

Leemans, I., \& G.J. Johannes, Worm en donder. Geschiedenis van de Nederlandse literatuur 1700180o: de Republiek, Bert Bakker, Amsterdam, 2013.

Lock, R., 'A history of practical work in school science and its assessment, 186o-1986', in: School Science Review 70, 1988, 115-119.

Meesterschapsteams Nederlands, Manifest Nederlands op school. 22 januari 2016. Digitaal raadpleegbaar: https://vakdidactiekgw.nl/manifest-nederlands-op-school/.

Meesterschapsteams Nederlands, Visie curriculum Nederlands. februari 2018. Digitaal raadpleegbaar: https://nederlands.vakdidactiekgw.nl/wpcontent/uploads/sites/4/2018/o2/VisieCurriculum-Nederlands-Meesterschapsteams1.5-definitief.pdf.

Meijer Drees, M., Nederlandse literatuur, een studiehandleiding, Wolters Noordhoff, Groningen, 1993.

Rens, E.M.M. van, Effectief scheikundeonderwijs voor 'leren onderzoeken' in de tweede fase van het vwo, dissertatie Vrije Universiteit Amsterdam, 2005.

Rijborz, D., Leren onderzoeken. Leerlijnen bij praktische opdrachten in de tweede fase in het profiel 'Economie \& Maatschappij', dissertatie Enschede, 2003. 
Rooij, E. van., Secondary school students' university readiness and their transition to university. dissertatie Rijksuniversiteit Groningen, 2018. Digitaal beschikbaar: https://www.rug.nl/research/ portal/files/545o6959/Complete_thesis.pdf

Roth, W.-M., 'Experimenting in a constructivist high school physics laboratory', in: Journal of research in science teaching 31, 1994, 197-223.

Schenkeveld-van der Dussen, R, \& T. Anbeek, Nederlandse literatuur, een geschiedenis, Wolters Noordhoff, Groningen, 1993 .

Schrijvers, M., T. Janssen \& G. Rijlaarsdam, 'Dat een boek kan veranderen hoe je naar de wereld kijkt. De impact van literatuuronderwijs op zelfinzicht en sociaal inzicht van bovenbouwleerlingen in havo en vwo', in: Levende Talen Tijdschrift 17, 2016, 3-13.

Sigmans, P. \& M. Kieft, 'Leerlingen onderzoeken lezen. Onderzoek in de les Nederlands', in: Levende Talen Magazine 7, 2007, 7-10.

Slings, H., Toekomst voor de Middeleeuwen. Middelnederlandse literatuur voor het voortgezet onderwijs, Bert Bakker, Amsterdam, 2000.

SLO, Eindexamenprogramma Geschiedenis. Geraadpleegd op http://www.slo.nl/downloads/archief/Examenprogramma_geschiedenis_DEFINITIEF.pdf.

SLO, Eindexamenprogramma Nederlands. Geraadpleegd op http://leerplaninbeeld.slo.nl/examenprogrammas/examenprogramma-nederlands-hv.pdf

Smits, T.J.M., Werken aan kwaliteitsverbetering van leerlingonderzoek. Een studie naar de ontwikkeling en het resultaat van een scholing voor docenten, dissertatie Enschede, 2003.

Smits-Veldt, M.B. \& K. Porteman, Een nieuw vaderland voor de muzen. Geschiedenis van de Nederlandse literatuur 1560-1700, Bert Bakker, Amsterdam, 2013.

Veenhoven, J., Begeleiden en beoordelen van leerlingonderzoek: een interventiestudie naar het leren ontwerpen van onderzoek in de tweede fase bij aardrijkskunde, dissertatie Universiteit Utrecht, Enschede, 2004.

Voet, M. \& B. de Wever, 'Onderzoekend leren, wat is dat? Naar een concrete invulling voor het schoolvak geschiedenis', in: Hermes 61, 2017, 12-18.

Wansink, B., Between fact and interpretation. Teachers' beliefs and practices in interpretational history teaching, Ridderkerk, 2017.

Witte, T., E. Mantingh \& M. van Herten, 'Doodtij in de Delta: Stand en toekomst van het Nederlandse literatuuronderwijs', in: Spiegel der Letteren 59, 2017, 1, 115-143.

Wientjes, H. \& J. Veenhoven, Eureka! Didactiek voor het leren onderzoeken in het vwo, Centrum voor Onderwijs en Leren, Utrecht, 2016.

Zande, E. van der, 'Het schoolvak Nederlands vandaag - en in de toekomst', in: Vaktaal 3, 2017, 11.

\section{Over de auteurs}

Lucas van der Deijl studeerde in 2016 af aan de Universiteit Utrecht (RMA Nederlandse letterkunde) en doet momenteel met steun van NWO als AiO aan de Universiteit van Amsterdam onderzoek naar het gebruik van tekst mining technieken in cultuurhistorisch onderzoek. Hij is daarnaast - middels een subsidie van het Prins Bernhard Cultuurfonds - bij de Universiteit Utrecht aangesteld als een van de redacteuren van LitLab. 
Feike Dietz is universitair docent Vroegmoderne Nederlandse letterkunde aan de Universiteit Utrecht, en docent aan de Hogeschool Utrecht, eerstegraadsopleiding Nederlands (MA). Ze heeft ruime ervaring met het ontwikkelen van (blended) leermateriaal voor middelbare en hogescholen en universiteit, en maakt sinds 2017 deel uit van de LitLab redactie. Ze heeft lezingen verzorgd over literatuuronderwijs op middelbare scholen (onder andere op de conferentie Het Schoolvak Nederlands (HSN) in 2017 en 2018), en begeleidt studenten bij stage- en scriptieprojecten voor middelbare scholen.

Els Stronks is hoogleraar Vroegmoderne Nederlandse letterkunde aan de Universiteit Utrecht. Zij heeft voor een aantal NWO-onderzoeksprojecten (Emblem Project Utrecht, Dutch Songs Online) digitale onderwijsmaterialen gemaakt voor middelbare scholen voor ze in 2016 LitLab startte. Ze heeft samen met de Internationale Vereniging voor Neerlandistiek (IVN) een subsidie van het Prins Bernhard Cultuurfonds verworven waarmee LitLab in de toekomst verrijkt kan worden met digitale Leesclubs en Proeven voor studenten neerlandistiek buiten Nederland en Vlaanderen.

Email: info@litlab.nl 
